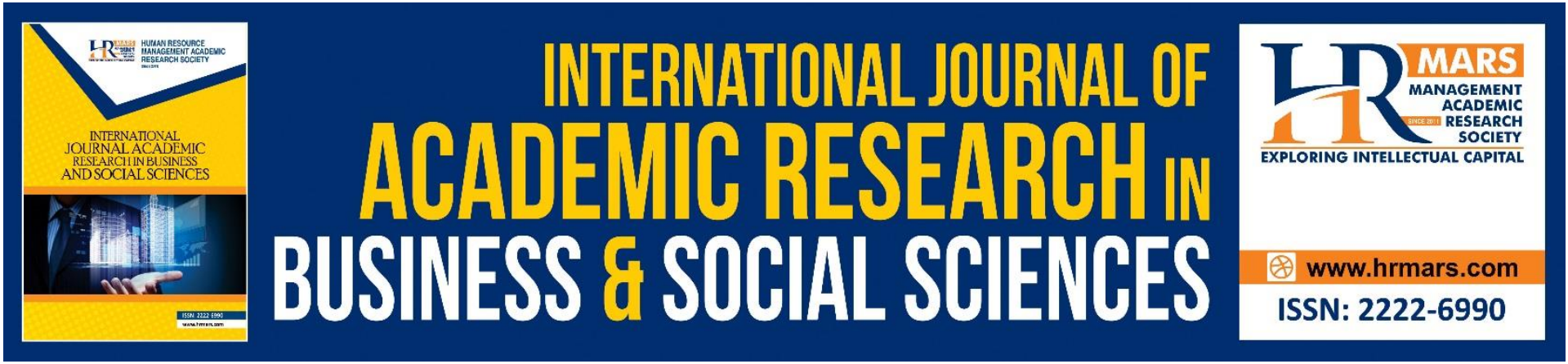

\title{
The Relationship of Risk Factors With Suicidal Ideation
}

\section{Muhamad Shamsul Ibrahim}

To Link this Article: http://dx.doi.org/10.6007/IJARBSS/v11-i2/9208

DOI:10.6007/IJARBSS/v11-i2/9208

Received: 13 December 2020, Revised: 17 January 2021, Accepted: 29 January 2021

Published Online: 27 February 2021

In-Text Citation: (Ibrahim, 2021)

To Cite this Article: Ibrahim, M. S. (2021). The Relationship of Risk Factors With Suicidal Ideation. International Journal of Academic Research in Business and Social Sciences, 11(2), 1332-1341.

Copyright: (c) 2021 The Author(s)

Published by Human Resource Management Academic Research Society (www.hrmars.com)

This article is published under the Creative Commons Attribution (CC BY 4.0) license. Anyone may reproduce, distribute, translate and create derivative works of this article (for both commercial and non-commercial purposes), subject to full attribution to the original publication and authors. The full terms of this license may be seen

at: http://creativecommons.org/licences/by/4.0/legalcode

Vol. 11, No. 2, 2021, Pg. 1332 - 1341

http://hrmars.com/index.php/pages/detail/IJARBSS

JOURNAL HOMEPAGE

Full Terms \& Conditions of access and use can be found at http://hrmars.com/index.php/pages/detail/publication-ethics 


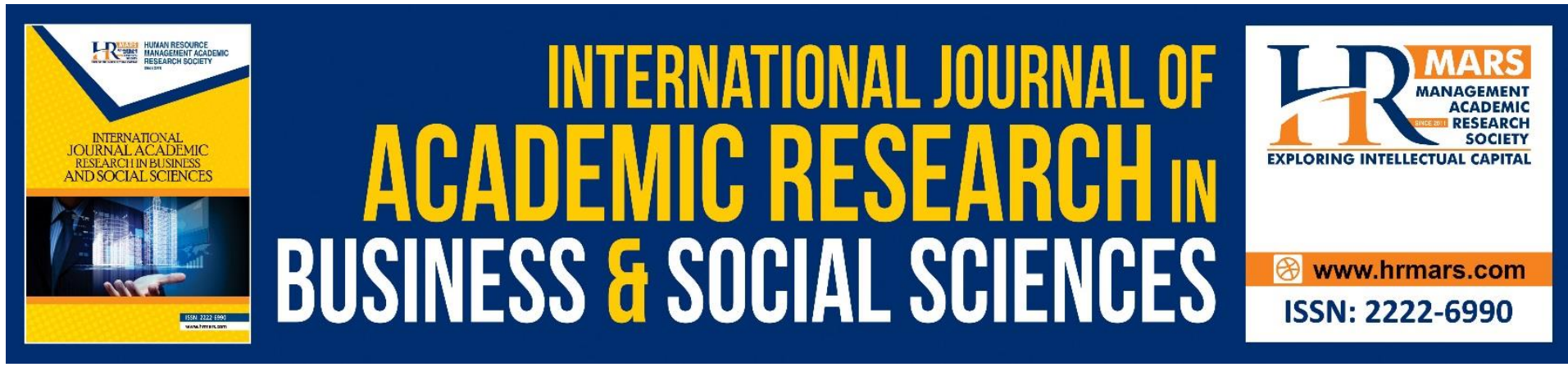

\title{
The Relationship of Risk Factors With Suicidal Ideation
}

\author{
Muhamad Shamsul Ibrahim \\ Kolej Universiti Poly-Tech MARA, 56100 Kuala Lumpur, Malaysia
}

\begin{abstract}
This study is to identify the relationship between thwarted belongingness, perceived burdensomeness, depression, perceived stress with suicidal ideation. The research aim is to determine the risk factor of suicidal ideation. The study used the survey to collect a response from 129 respondents. The respondents were students from Kolej Universiti Poly-Tech Mara Kuala Lumpur and were selected randomly. The findings indicated that all the independent variables are correlated to suicidal ideation. The finding is an essential contribution to knowledge development, especially to understand the possible triggering factors in youth to commit suicide.
\end{abstract}

Keywords: Suicidal Ideation, Thwarted Belongingness, Perceived Burdensomeness, Depression, Perceived Stress

\section{Introduction}

Suicidal ideation can be defined as thoughts, ideas and the desire among adolescents to commit suicide. It has become a severe public health problem. Suicidal ideation is considered a vital predictor of a potential suicide threat. According to the World Health Organisation (2002), suicide has become the world second-largest cause of death among the students and young adults. Globally, suicide incidents is one of the three leading causes of death among those aged 15 to 44 (Bernama, 2020).

In Malaysia, the prevalence of the adolescents suicidal behaviour is troubling even though Malaysia was reported one of the countries with the lowest completed suicide rate, which is $0.6 \%$ over 100,000 person (Chan et al., 2016). According to Kok and Goh (2011), 7\% of the adolescents in Malaysia has the plan to commit suicide, where half of them have attempted suicide.

The local newspaper reported that the youngest rescued from suicide was a 15-year-old girl from East Coast Malaysia (Benjamin \& Devi, 2020). Another news reported extreme criticism by the netizen was a cause to cyberbullying victim death after her Tik Tok video went viral on social media (Lo, 2020). Illogical action by many children and youths in Malaysia shows that they are suffering from a mental health problem. They are under pressure because of several factors like the problem in school, fears about their future, and cyberbullying. A shocking fact is that bullying is perceived merely as one of the social issues in Malaysia. However, the case 
is worsening each day where the victims are continuously oppressed in many forms like slander, curse and insult (Rashid \& Mohamad, 2016). The victim started to experience anxiety, depression and panic attacks (Hassan, 2019). Hence, the victim feels depress and lead to suicidal thought repeatedly.

Suicidal ideation is no longer merely an issue in the community but has become an alarming problem. The Health Minister also shared his concern when suicide attempt cases are getting more worrying (Bernama, 2020). In this research, a student at the tertiary level is easily exposed to mental health problem because of several reasons. For instance, overwhelm burden, depress and stress, to meet the academic high standard requirement and expectation from peers. Therefore, it is worth to conduct this study to identify the possible risk factors which could lead to suicidal ideation. The study is critical because the findings contributed to a better understanding of possible factors to suicidal ideation among teenagers. In general, the study has achieved the general objective to find the relationship of the cause with the youth suicidal ideation.

\section{Literature Review}

\section{Relationship between Thwarted Belongingness and Suicidal Ideation}

The study refers to thwarted belongingness as social isolation, where one will experience a lack of social connectedness. For example, the individual will often have thoughts that he is alone, or there are no people he can turn to in times of need (Acosta, Hagan \& Joiner, 2017). Joiner (2005) emphasis that in the interpersonal theory of suicide, thwarted belongingness is the strongest predictors for suicidal ideation compared to perceived burdensomeness. The theory highlighted that that belongingness is a basic human need. When this need failed to be met, individuals experience emotional and psychological pain, which may result in suicidal thoughts. The individual who experiences social disconnectedness is still exposed to suicidal thoughts and desire, although without the capability to commit suicide. Thus, thwarted belongingness is a primary and essential factor related to suicidal ideation. (Ploskonka \& Servaty-Seib, 2015).

The student mental health is related to the domains of belongingness, namely their family, peers, and academics. However, the suicidal ideation may exist between these domains of belongingness if the student feels disconnected. Therefore, to meet the study objective, the research is an attempt to discover whether the domains of belongingness are connected with suicidal ideation based on the following hypothesis:

$\mathrm{H} 1$ : There is a relationship between thwarted belongingness and suicidal ideation.

\section{Relationship between Perceived Burdensomeness and Suicidal Ideation}

Besides thwarted belongingness, this study also researched perceived burdensomeness. According to the interpersonal theory of suicide, perceived burdensomeness is when one believes that the individual is a burden or a nuisance to other people such as friends, family members, and society. The individual generated illogical thought where their death is worth more than their life (Joiner, 2005). Some psychiatric report also agreed that perceived burdensomeness appears to be a risk factor for suicide ideation among psychiatric inpatients. (Jahn, Cukrowicz, Mitchell, Poindexter \& Guidry, 2015). According to the interpersonal theory of suicide, perceived burdensomeness could contribute to suicidal ideation if the youth showed low family connectedness. Briefly, an individual possibly would think to commit 
suicide only if the individual has a low family connectedness and high burdensomeness and both factors are present together. The person who craves to feel accepted or belong to a family and feel like a burden on others that are ones at higher risk (Opperman et al., 2015).

Besides that, perceived burdensomeness plays a vital role in the relationship between mental functioning and suicide risk. For example, suppose individuals have low ability to self-monitor. In that case, they may underestimate themselves to others or misjudge their effectiveness in daily activities. This misjudgement may create feelings of liability or burdensomeness to others, which may be related to suicide risk. Similarly, suppose individuals believe that they cannot solve their problems and feel that they need the assistance of others to help with problem-solving. In that case, they may feel like a burden on those in their lives, which will increase the suicide risk (Jahn, Cukrowicz, Mitchell, Poindexter \& Guidry, 2015). Therefore, to meet the study objective, the following hypothesis is proposed:

$\mathrm{H} 2$ : There is a relationship between perceived burdensomeness and suicidal ideation.

\section{Relationship between Depression and Suicidal Ideation}

Depression or major depressive disorder is a common and serious medical illness that negatively affects how people feel, the way one think and act. Fortunately, it is also treatable. Depression causes feelings of sadness and/or a loss of interest in activities once enjoyed. It can lead to a variety of emotional and physical problems. It can decrease individual ability to function at work and home (American Psychiatric Association, 2017).

Depression is an independent factor and one of the essential predictors to suicidal ideation (Barzilay and Apter, 2014; Barzilay et al., 2015). According to Bailey, Robinson \& McGorry, (2018) besides medical practitioners, students also at high risk to experience stress and burnout. Coined from the National Evidence-based healthcare Collaborating Agency (NECA) report, the most critical factor that leads adolescents to suicide ideation is depression. The report stated that $68 \%$ of students answered that they had experienced depression, and $45 \%$ have experienced suicide ideation in South Korea. The results indicated that more than half of the students went through depression before reaching suicide ideation. Therefore, the researchers assume that depression was an essential factor that made them think of suicide (Zong, 2015). Therefore, the following hypothesis is formulated to meet the study objective.

H3: There is a relationship between depression and suicidal ideation.

\section{Relationship between Perceived Stress and Suicidal Ideation}

Stress is a natural physiological mechanism that protects humans from danger. But continual exposure to stress lead to physical and psychological illnesses. For example, obesity, gastrointestinal disorders, cardiovascular disorders, skin disorders, anxiety attacks, and depression (Anbumalar, Dorathy, Jaswanti, Priya, \& Reniangelin, 2017). While according to Philips (2013), perceived stress comprises of the uncontrollability and unpredictability feelings. The feeling is dynamic whenever an individual must deal with hassles, changes in life, and related individual ability to deal with problems or difficulties. The research is agreed with the given definition and concluded that perceived stress as how an individual feels about the general stressful events in their life and their ability to handle the stress. 
The earlier studies in abroad show that perceived stress is one of the contributors to suicidal ideation for all age groups. A study in Pakistan indicated that the majority of students are in incredible stress due to study-related because of poor performance in exams and massive workload. Many of the students did think to die because they are unable to cope with the burden (Osama et al., 2014). A study in Saudi Arabia also reported that many students in the country are experiencing mounting stress levels (Gazzaz et al., 2018). The previous literature indicated a clear relationship between the stress and suicidal ideation in abroad. Thus, the study assumes that a similar relationship also could be found in this research. Hence the following hypothesis is formulated.

$\mathrm{H} 4$ : There is a relationship between perceived stress and suicidal ideation.

Therefore, the study developed its conceptual framework to measure the possible factors to suicidal ideation by including the thwarted belongingness, perceived burdensomeness, depression, and perceived stress as shown in figure 2.1.

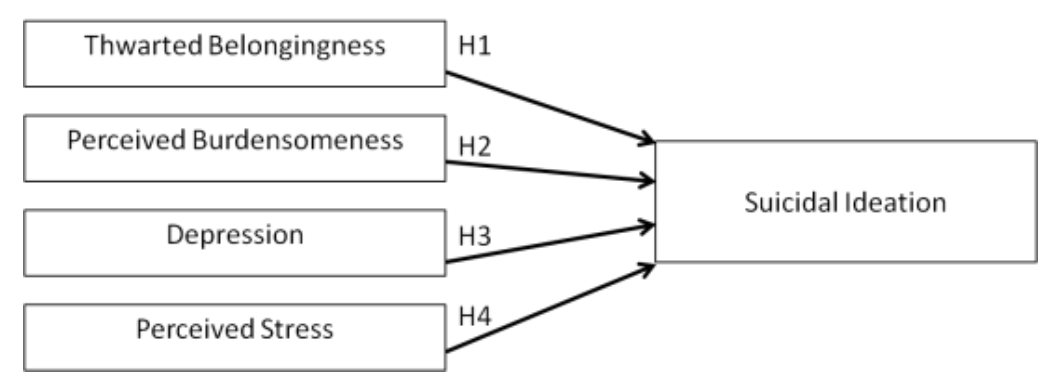

Figure 2.1. Conceptual Framework of Risk Factors with Suicidal

\section{Methodology}

The study aim was to find the relationship between the possible factors that contributed to suicidal ideation. Thus, the study decided to use a quantitative approach to meet the research objective. According to Bhat (2020) quantitative research collects input from the current and prospective consumers using the online surveys, web polls, or questionnaires, which the findings of which can be presented in numerical form.

The study applied-rule-of thumbs principal to determine the number of samples to be collected in the preliminary study to determine the instrument validity and reliability. Hence, the study successfully collected 129 responses. The study applied a random sampling technique to collect the data because it is easy, less in cost and convenient to use (Etikan and Bala, 2017). The unit of analysis for this study is the respondent who is studying in KUPTM KL around 18 to 25 years old.

The study used an online survey to determine the risk factors of suicidal ideation among undergraduate students in a university. The questionnaire consisted of 52 questions. The questions were adopted and adapted from the past researches like Sidik, Arroll, GoodyearSmith, and Ahmad, 2012; Hill, Rey, Marin, Sharp, Green, and Pettit, 2015; McLean et al., 2017). The measurement for the questionnaire consists of the five-point Likert scale from 1-Never, 2-Rarely, 3-Sometimes, 4-Often and 5-Always.

The study conducted a preliminary study to minimise the validity and reliability issue. The study performed a content validity check by sending the proposed items to the content expert to verify the suitability of the item for measuring the selected variable. 
While for the reliability test, the items are considered reliable if the Cronbach alpha value is more than 0.7 (Hulin, Netemeyer, and Cudeck; 2001; Britton, 2020). The purpose of the reliability test is to measure how well a test to measure what is should be (Linn and Gronlund, 2000; Carlota, 1987). Thus, the variable in this study is considered reliable and ready for the actual data collection because it met the Cronbach alpha value requirement. The value are as follow: suicide ideation, $\alpha=0.86$, depression, $\alpha=0.7999$, perceived stress, $\alpha=0.72$, thwarted belonging, $\alpha=0.941$ and perceived burdensomeness, $\alpha=0.79$.

The study used Statistical Package for the Social Sciences (SPSS) to analyse the data. The data were analysed descriptively and inferential. A descriptive analysis is used to describe the respondent background. In contrast, for inferential analysis, the study used a correlation to test the hypotheses.

\section{Findings and Discussion}

The analysis indicated there are $66 \%$ of male and $34 \%$ of the female have responded to this study. The participated respondents are in between 18 to 25 years old. It was found that $75 \%$ of the respondent are from 23 to 25 years old. Majority of the respondents are from semester five, six, and seven. The demographic analysis showed that the study only focuses on the youth, which is part of the member of young people. The United Nations (n.d) defined youth as the individual between the ages of 15 to 24 years old. Thus, this issue is pertinent to be addressed based on the report made by Kok and Goh (2011) that 7\% of the adolescent in Malaysia has the intention to commit suicide. The study on young people is crucial because of the intention to commit suicide has started during the adolescent.

The study conducted a correlation analysis to test the research hypothesis. The relationship strength between the variables is determined based on the Guilford Rule of Thumb.

Table 4.7. Correlation test between thwarted belongingness (TB) and suicidal ideation (SI)

\begin{tabular}{|l|c|c|c|}
\hline & $\boldsymbol{r}$ & $\boldsymbol{p}<.05$ & Result \\
\hline TB $--->\mathrm{SI}$ & 0.324 & .000 & Significant \\
\hline
\end{tabular}

Table 4.7 indicated that $\mathrm{H} 1$ is supported where there is a low correlation between thwarted belongingness and suicidal ideation. The youth who always feel isolated has a high thwarted belongingness reported that they often undergo suicidal thoughts. The probable explanation to this relationship is because the majority of the respondents felt fortunate that caring family member and friends surround them. Only several of them felt isolated in many social situations. The respondent felt a high sense of belongingness. As a consequence, they do not feel worried and lonely, which eventually might lead to suicidal ideation.

Table 4.8. Correlation test between perceived burdensomeness (PB) and suicidal ideation

(SI)

\begin{tabular}{|l|l|r|c|}
\hline & $\boldsymbol{r}$ & $\boldsymbol{p}<.05$ & Result \\
\hline PB ---> SI & 0.444 & .000 & Significant \\
\hline
\end{tabular}

Table 4.8 showed that $\mathrm{H} 2$ is also supported. The result indicated there is a moderate relationship between the perceived burdensome and suicidal ideation. The analysis pointed out that the perceived burdensomeness has the highest strength of affiliation with suicidal ideation compared to other factors in this study. The possible explanation for this relationship is because the majority of the respondents felt that they are almost unable to contribute to the other people that are important in their life. They also felt that they had failed the people that close to them. Besides, they have a thought that the persons they care would be happier 
without them. Thus, the intention to commit suicide occur without the association and closeness to people and heightens the level of fear of missing out.

Table 4.9. Result of correlation test between depression (D) and suicidal ideation (SI)

\begin{tabular}{|c|c|c|c|}
\hline & $\mathbf{r}$ & $\boldsymbol{p}<.05$ & Result \\
\hline $\mathrm{D}--->\mathrm{SI}$ & 0.356 & .000 & Significant \\
\hline
\end{tabular}

Further, the analysis also showed that $\mathrm{H} 3$ is supported where there is a low relationship between depression and suicidal ideation. Respondents disclose of having suicidal intentions when they undergo depression. Most of the respondents agree that sleep is an essential factor of depression. Majority of individuals with depression experience sleep disturbances; therefore sleep strongly influences depression (Franzen \& Buysse, 2008). The likely clarification to this is because the often the respondents lack of sleep or excessive sleep often felt tired, and lost interest or motivation in doing a thing. As a result, it may positively lead to depression and suicidal ideation. The analysis found that after the perceived burdensomeness, depression is to be one of the vital factors associated with the respondent suicidal ideation. Higher the depression level will increase the risk of suicidal ideation.

Table 4.9. Result of correlation test between perceived stress (PS) and suicidal ideation

(SI)

\begin{tabular}{|c|c|c|c|}
\hline & $\mathbf{r}$ & $\boldsymbol{p}<.05$ & Result \\
\hline PS --->SI & 0.346 & .000 & Significant \\
\hline
\end{tabular}

Table 4.9 indicated that $\mathrm{H} 4$ is supported. As hypothesised, there is a low relationship between perceived stress and suicidal ideation. The likely explanation to this finding if individual lack of control in emotion such as being unable to handle problems, excessively being nervous, angered and worried, it might trigger the idea to commit suicide. Self-confidence is essential in handling stressful situations, and confidence will make a person better (Boe \& Hagen, 2015). The study believes feeling confident will help to reduce stress level. Thus, a stressful individual tends to have the intention to commit suicide-vital factors associated with the respondent suicidal ideation. The participants who answered "always","often" and "sometimes" shows a higher tendency of having suicidal intentions.

\section{Conclusion}

Suicidal ideation is now a critical issue in public health that puts severe social and economic strains on the population. Combined with several factors such as the demographic, biological, psycho-social, and psychiatric risk factors, is an exceedingly complex phenomenon. Despite the number of risk factors, the individual risk of suicide or suicide attempt by any given person is low. Treatments are complicated because of the diverse nature of factors leading to suicide and the relatively low population rate. In the diversity of studies aimed at recognising and preventing suicidal behaviours, the difficulty of suicide is reflected. The analysis during the preliminary study on 129 youth, indicated that the youth intention to commit suicide or known as suicidal ideation is caused by thwarted belongingness, perceived burdensomeness, depression, and perceived stress. The better mental state will create a safer and healthier society. However, from time to time, many people will experience mental health issues.

The study wishes to recommend several ideas on overcoming the stigma related to the mental health issue. First, to hold an open discussion on the mental health issue. Schools or 
institutions need to maximise the number of mental health talks to discuss related problem and transparency during the discussion is highly recommended. Second, to always educate ourselves and others. The society will be a better place if the members are knowledgeable. Third, to show empathy to those who have a mental health issue. Giving a smile to others and willing to listen to others will encourage others to repeat the same attitude to others. A wise man did mention; a good deed is contagious.

There are several limitations the study wishes to address for the future study. First, the study experiences the constraint to get an adequate number of sample. The only method is via an online medium such as the WhatsApp or telegram. The respondent would not even bother to participate in the study. Therefore, the study suggested focusing on the use of online applications such as Whatsapp, Instagram, Facebook, Twitter, and Email to perform the survey. A wide range of medium is influencing the number of respondents. Second, most of the respondents did not seem aware that they have a mental illness. Thus, more questions that related to mental illness symptoms could be included to identify the respondent suitability.

\section{Acknowledgement}

Massive thank you to Kolej Universiti Poly-Tech MARA Kuala Lumpur and Universiti Pendidikan Sultan Idris for the support, especially during the data collection process. It was almost impossible to do during the pandemic Covid-19.

\section{Corresponding Authors}

Sarina Yusuf, Universiti Pendidikan Sultan Idris, Malaysia, sarinayusuf@fbk.upsi.edu.my Sri Durghasheni Muthamil Maran, Kolej Universiti Poly-Tech MARA Kuala Lumpur, Malaysia Nur Amirah Eusni Ahmad Fathil, Kolej Universiti Poly-Tech MARA Kuala Lumpur, Malaysia Nursyamimi Ruazaman, Kolej Universiti Poly-Tech MARA Kuala Lumpur, Malaysia

\section{References}

Acosta, L., Hagan, C., \& Joiner, T. (2017). Burdensomeness, Belongingness, and Suicidal Desire Among Hispanic/Latino Individuals: Examining the Effect of Ethnicity in the Interpersonal Theory of Suicide. Psi Chi Journal of Psychological Research, 22(1), 54-63. https://doi.org/10.24839/2325-7342.JN22.1.54

American Psychiatric Association. (2017). What Is Depression?. Retrieved April 20, 2020, from https://www.psychiatry.org/patients-families/depression/what-is-depression.

Anbumalar, C., Dorathy, A. P., Jaswanti, V. P., Priya, D., \& Reniangelin, D. (2017). Gender differences in perceived stress levels and coping strategies among college students. International Journal of Indian Psychology, 4(4), 22-33. https://doi.org/10.25215/0404.103

Bailey, E., Robinson, J., \& McGorry, P. (2018). Depression and suicide among medical practitioners in Australia. Internal Medicine Journal, 48(3), 254-258. https://doi.org/10.1111/imj.13717

Barzilay, S., \& Apter, A. (2014). Predictors of suicide in adolescents and adults with mood and common comorbid disorders. Neuropsychiatry, 4(1), 81. https://doi.org/ 10.2217/NPY.13.86

Barzilay, S., Feldman, D., Snir, A., Apter, A., Carli, V., Hoven, C. W., Wasserman, C., Sarchiapone, M., \& Wasserman, D. (2015). The interpersonal theory of suicide and 
adolescent suicidal behavior. Journal of affective disorders, 183, 68-74. https://doi.org/10.1016/j.jad.2015.04.047

Bernama. (2020). 465 attempted suicide cases in first half this year. Retrieved from https://www.dailyexpress.com.my/news/158199/465-attempted-suicide-cases-infirst-half-this-year-/

Benjamin, N., \& Devi, V. (2020). Suicides spike during MCO. Retrieved from https://www.thestar.com.my/news/nation/2020/08/11/suicides-spike-during-mco

Boe, O., \& Hagen, K. (2015). Using mindfulness to reduce the perception of stress during an acute stressful situation. Procedia - Social and Behavioral Sciences, 197, 858868. https://doi.org/10.1016/j.sbspro.2015.07.262

Britton, D. (2020). Suny Empire State College. Retrieved from SPSS eTutor: Constructing Scales and Checking Their Reliability: https://subjectguides.esc.edu/c.php?g=659059\&p=4626861

Carlota, A. J. (1987). Psychological measurement in the Philippines: A book of readings. Quezon City: UP Psychology Foundation.

Chan, Y. Y., Lim, K. H., Teh, C. H., Kee, C. C., Ghazali, S. M., Lim, K. K., Khoo, Y.Y., Tee, O.E., Ahmad, N.A., \& Ibrahim, N. (2016). Prevalence and risk factors associated with suicidal ideation among adolescents in Malaysia. International Journal of Adolescent Medicine and Health, 30(3). https://doi.org/10.1515/ijamh-2016-0053

Cohen, L., Manion, L. \& Morrison, K. (2000). Research methods in education (5th ed.). London: Routledge/Falmer.

Etikan, I., \& Bala, K. (2017). Sampling and Sampling Methods. Biometrics \& Biostatistics International Journal, 5(6): 00149. https://doi.org/ 10.15406/bbij.2017.05.00149

Franzen, P. L., \& Buysse, D. J. (2008). Sleep disturbances and depression: risk relationships for subsequent depression and therapeutic implications. Dialogues in clinical neuroscience, 10(4), 473. https://doi.org/ 10.31887/DCNS.2008.10.4

Gazzaz, Z., Baig, M., Al Alhendi, B., Al Suliman, M., Al Alhendi, A., Al-Grad, M., \& Qurayshah, M. (2018). Perceived stress, reasons for and sources of stress among medical students at Rabigh Medical College, King Abdulaziz University, Jeddah, Saudi Arabia. BMC Medical Education, 18(1). https://doi.org/10.1186/s12909-018-1133-2

Hassan, H. (2019). Malaysian police investigate case of teen who committed suicide after Instagram poll. Retrieved from https://www.straitstimes.com/asia/se-asia/malaysianpolice-investigate-case-of-teen-who-committed-suicide-after-instagram-poll

Hill, R. M., Rey, Y., Marin, C. E., Sharp, C., Green, K. L., \& Pettit, J. W. (2015). Evaluating the Interpersonal Needs Questionnaire: Comparison of the reliability, factor structure, and predictive validity across five versions. Suicide and Life-Threatening Behavior, 45(3), 302-314. https://doi.org/10.1111/sltb.12129

Hulin, C., Netemeyer, R., and Cudeck, R. (2001). Can a Reliability Coefficient Be Too High? Journal of Consumer Psychology, Vol. 10, Nr. 1, 55-58

Jahn, D. R., Cukrowicz, K. C., Mitchell, S. M., Poindexter, E. K., \& Guidry, E. T. (2015). The Mediating Role of Perceived Burdensomeness in Relations Between Domains of Cognitive Functioning and Indicators of Suicide Risk. Journal of Clinical Psychology, 71(9), 908-919. https://doi.org/10.1002/jclp.22190

Joiner, T. E., Jr. (2005). Why people die by suicide. Cambridge, MA: Harvard University Press. Joiner, T., Pettit, J., Walker, R., Voelz, Z., Cruz, J., Rudd, M., \& Lester, D. (2002). Perceived Burdensomeness and Suicidality: Two Studies on The Suicide Notes of Those Attempting 
And Those Completing Suicide. Journal of Social and Clinical Psychology, 21(5), 531-545. https://doi.org/10.1521/jscp.21.5.531.22624

Kok, J. K., \& Goh, L. Y. (2011). Young people and suicide issue. In International Conference on Humanities, Society and Culture (Vol. 20, pp. 32-36).

Linn, R. L., \& Gronlund, N.E. (2000). Measurement and assessment in teaching. 8th ed. New Jersey: Prentice Hall.

Lo, T. C. (2020). Cyberbullying victim leaves suicide note. Retrieved from https://www.thestar.com.my/news/nation/2020/05/22/cyberbullying-victim-leavessuicide-note

McLean, C. P., Zang, Y., Zandberg, L., Bryan, C. J., Gay, N., Yarvis, J. S., Foa, E. B., \& Strong Star Consortium. (2017). Predictors of suicidal ideation among active duty military personnel with posttraumatic stress disorder. Journal of affective disorders, 208, 392-398. https://doi.org/10.1016/j.jad.2016.08.061

Opperman, K., Czyz, E. K., Gipson, P. Y., \& King, C. A. (2015). Connectedness and Perceived Burdensomeness among Adolescents at Elevated Suicide Risk: An Examination of the Interpersonal Theory of Suicidal Behavior. Archives of Suicide Research, 19(3), 385-400. https://doi.org/10.1080/13811118.2014.957451

Osama, M., Islam, M. Y., Hussain, S. A., Masroor, S. M. Z., Burney, M. U., Masood, M. A., Menezes, R.G., \& Rehman, R. (2014). Suicidal ideation among medical students of Pakistan: a cross-sectional study. Journal of forensic and legal medicine, 27, 65-68. https://doi.org/10.1016/j.jflm.2014.08.006

Phillips, A. (2013). Perceived Stress. Encyclopedia of Behavioral Medicine, 1453-1454.

Ploskonka, R., \& Servaty-Seib, H. (2015). Belongingness and Suicidal Ideation in College Students. Journal of American College Health, 63(2), 81-87. https://doi.org/10.1080/07448481.2014.983928

Rashid, A. R., \& Mohamad, A. (2016). New media narratives and cultural influence in Malaysia. The strategic construction of blog rhetoric by an apostate. New York, Springer.

Sidik, S. M., Arroll, B., Goodyear-Smith, F., \& Ahmad, R. (2012). Prevalence of depression among women attending a primary urban care clinic in Malaysia. Singapore Med J, 53(7), 468-473.

United Nations (n.d). Definition of youth [Fact sheet]. United Nations Department of Economic and Social Affairs. https://www.un.org/esa/socdev/documents/youth/factsheets/youth-definition.pdf

World Health Organization. (2002). The world health report 2002: reducing risks, promoting healthy life. World Health Organization.

Zong, S. (2015). A Study on Adolescent Suicide Ideation in South Korea. Procedia - Social And Behavioral Sciences, 174, 1949-1956. https://doi.org/10.1016/j.sbspro.2015.01.860 